\title{
Green Accounting, Financial Literacy, and Financial Performance: A Case Study on Sukaregang Tannery Industrial Center in Garut, West Java Indonesia
}

\author{
Valyanisa Byzzanthi ${ }^{1}$, Wita Juwita Ermawati ${ }^{2}$ \\ \{byzzanthi_valya@apps.ipb.ac.id ${ }^{1}$,witaman@apps.ipb.ac.id $\left.{ }^{2}\right\}$ \\ Faculty of Economics and Management, IPB University, Bogor ${ }^{1,2}$
}

\begin{abstract}
An increasing number of manufacturing industries have a significant impact on environmental sustainability issues. Green accounting is one of the alternatives that measures the environmental impact of human activity on the earth's ecological systems and resources. This research aims to analyze the implementation of green accounting, financial literacy, and financial performance at Sukaregang Tannery Industrial Center. The primary data are collected through in-depth and quetionnaire-based structured interviews, while the secondary data are acquired from a review of the literature. The analytical methods used in this research is quantitative analysis. Results from this research indicates that the level of implemetation of green accounting for tanners in Sukaregang is mostly included in the moderate category with a percentage of $57.14 \%$ and the majority of owners of tannery industry in Sukaregang have a low level of financial literacy with a percentage of $42.86 \%$. Green accounting and financial literacy has a strong correlation with a correlation coefficient of 0.601 . However, green accounting and financial literacy do not have a significant correlation with financial performance.
\end{abstract}

Keywords: financial literacy, financial performance, green accounting, tannery industry.

\section{Introduction}

The manufacturing sector is one of the main components of national economic development [1]. Indonesia's economic growth, which is measured by Gross Domestic Product (GDP) by business fields, shows that the manufacturing industry is the highest source of economic growth in Indonesia between 2017 and 2019, compared to the infocom, construction, and trade sectors. Indonesia's economic growth rate in 2017 based on the manufacturing sector source was $18.14 \%$, in 2018 it was $17.60 \%$, and in 2019 it was $15.93 \%$

${ }^{1}$ Undergraduate Student of Management Department, FEM IPB

${ }^{2}$ Lecturer of Management Department, FEM IPB 
[2]. This significant GDP contribution implies the importance of continuing efforts towards improving the manufacturing sector performance. The production index is one of the main indicators to measure the growth of manufacturing industry production [1]. In 2011-2019, the manufacturing industry production index has increased every year $[3,4]$.

Apart from having an impact on the economic aspect, industrial growth also has an impact on the environment and social aspect. For a social perspective, the industry tends to have positive impacts such as reducing the unemployment rate, increasing the welfare of the community around industrial estates, and so on. While with regard to the environmental aspect, the industry have so many negative impacts such as water pollution, air pollution, and many others [5].

A challenge occured from the increase in business and industrial activities includes waste management. Apart from increasing the volume of waste produced, various consumption also affects the material composition of the waste container, which becomes increasingly difficult to decompose naturally, polluting the environment, and endangering human health. Waste is categorized into hazardous and toxic waste materials and non-hazardous and toxic waste materials waste. Generally, hazardous and toxic waste materials waste comes from industrial activities, while non-hazardous and toxic waste materials waste comes from domestic waste, agricultural waste, and some industrial waste [6].

Along with the times, a company is required not only to pay attention to profit, but several things need to be considered, such as social and environmental aspects (Elkington 1997). These three aspects are known as the Triple Bottom Line (TBL) with the 3P formulation (people, planet, and profits) [7].

Tannery industry is one of the most polluting industries for the environment [8]. Almost every tannery industry uses large amounts of chemicals during the leather tanning process [9]. The tannery industry produces solid and liquid waste containing hazardous waste. On every processing of $100 \mathrm{~kg}$ of raw skin into tanned skin, 3000 liters of waste is reduced [9] and about $60 \mathrm{~kg}$ of solid waste [10].

Sukaregang tannery industrial center in Garut is arguably the most famous producer of leather products in Indonesia [11]. Yet the status of the average water quality in the Cimanuk Watershed, if evaluated by the STORET method and seen from the monitoring point in the Sukaregang area shows that the water quality status is classified as is in the "Severely Polluted" status with a STORET score of -48 [12]. This has led to serious concerns, so environmentally friendly alternatives are needed.

Accumulating pieces of evidence constantly indicate that the transition of the existing industries into the eco-industrial network through the successful 
implementation of green approaches provides a viable solution to preserve the natural resources of the region while concurrently enhances the regional economy on a sustainable basis [13]. Green accounting is a type of accounting that attempts to factor environmental costs into the financial results of operations [14]. The major purpose of Green accounting is to help businesses understand and manage the potential quid pro quo between traditional economics goals and environmental goals [15].

When it comes to purchasing behavior, it's become abundantly clear that consumers care. In fact, the majority (73\%) of global consumers say they would definitely or probably change their consumption habits to reduce their impact on the environment. As consumers become increasingly aware of what they put in and on their bodies, they're also interested in buying - and sometimes paying more - for products that simultaneously help the environment [16].

Fifty-five percent of global online consumers across 60 countries say they are willing to pay more for products and services provided by companies that are committed to positive social and environmental impact, according to a new study by Nielsen [17]. The impulse to "go green" is clearly gaining momentum. According to a recent study in the UK and America, said that half of the digital consumers say environmental concerns impact their purchasing decisions [18]. In one recent survey, $65 \%$ said they want to buy purpose-driven brands that advocate sustainability [19].

Environmentally induced economic risks can have a profound effect on company performance and competitive ability. Especially the risk absorption potential of SMEs is limited due to scarce, particularly financial, resources. Thus assessing and evaluating the nature and potentiality of risks becomes important [20].

In 2016, the number of tannery industries in Garut was 247 businesses, most of which were MSMEs. However, the number has decreased year by year, then in 2019 it just remains 282 tannery industries in the Sukaregang leather industry center area [21]. The decline was most likely because of the industry's lack of competitiveness. This is because about $69 \%$ and $30 \%$ of Indonesian manufactured products traded in the ASEAN region have low and moderate competitiveness, respectively. Only about $1 \%$ of domestic industrial products have strong competitiveness [22].

A green competitive advantage is a potential for environmental performance to improve long term profitability [23]. Firms also can achieve competitive advantage and improve their performance by collective and tacit knowledge as a key resource, then it comes to improve organizational performance. SMEs are generally characterized by a lack of financial knowledge and managerial skills. Financial literacy has been identified as a vital knowledge resource for financial 
decision making [24] and helping to increase SMEs' sustainability [25]. A survey that OJK conducted in 2013 on national financial literacy in Indonesia showed that the financial literacy rates among MSMEs stood only at $15.7 \%$, lower than the national average rates of $21.8 \%$ on financial literacy [26].

\section{Research Methodology}

\section{1 Sample Design and Data Collection}

This research was conducted at the Sukaregang Tannery Industry Center in Garut, West Java. The sampling method in this study is non-probability sampling with a purposive and snowball sampling technique. Sampling is terminated when no new information is forthcoming from newly sampled units, thus redundancy level is the primary criterion. The sample in this research is limited because of lockdown policy by the local goverment due to the pandemic Covid-19, thus the process of collecting data is inhibiting.

The primary data are collected as quantitative data through in-depth and questionnaire-based structured interviews, while the secondary data is acquired from literature studies. A survey using a questionnaire was distributed to the owners of the Sukaregang tannery industry to collected the quantitative data.

Profile of the sample in this research includes gender, age, academic standings, reasons start the business, industry category, and business age presented in Table 1.

Table 1. Profile of the sample

\begin{tabular}{llcc}
\hline Characteristics & \multicolumn{1}{c}{ Category } & Frequency & Percentage (\%) \\
\hline Gender & Male & 12 & 85.7 \\
& Female & 2 & 14.3 \\
\hline Age & $17-25$ years & 0 & 0 \\
& $26-35$ years & 1 & 7.1 \\
& $36-45$ years & 5 & 35.7 \\
& $46-55$ years & 5 & 35.7 \\
& $56-65$ years & 3 & 21.5 \\
& $>65$ years & 0 & 0 \\
\hline Academic & Did not finish school & 1 & 7.1 \\
Standings & Elementary School/Equivalent & 0 & 0 \\
& Junior High School/ Equivalent & 1 & 7.1 \\
& Senior High School/ Equivalent & 8 & 57.2 \\
& Bachelor & 2 & 14.3 \\
& Others (Diploma/Academic) & 2 & 14.3 \\
\hline
\end{tabular}




\begin{tabular}{llcc}
\hline \multicolumn{1}{c}{ Characteristics } & \multicolumn{1}{c}{ Category } & Frequency & Percentage (\%) \\
\hline Reasons start the & Own desire & 5 & 35.7 \\
business & Hereditary & 9 & 64.3 \\
& Joining business with friends & 0 & 0 \\
& Others & 0 & 0 \\
\hline Industry Category & Micro Industry & 8 & 57.2 \\
& Small Industry & 1 & 7.1 \\
& Medium Industry & 5 & 35.7 \\
& Big Industry & 0 & 0 \\
\hline Business Age & 1 - 5 years & 0 & 0 \\
& 5 - 10 years & 0 & 0 \\
& >10 years & 14 & 100 \\
\hline
\end{tabular}

\section{2 Measurement of Variables}

\section{Green Accounting}

The implementation of green accounting measured by questionnaire with 4 dimensions and 24 indicators which is adapted from the previous studies, there are environmental awareness [27] with 6 indicators, environmental protection [28] with 4 indicators, environmental involvement [28] with 4 indicators, and environmental reporting [29] with 10 indicators (see Appendix A). Responses were given using a five-point Likert scale. The index value for each indicator and categorization for each level of green accounting is calculated using a threebox method [30]. The categorization for each level of green accounting is shown in Table 2.

Table 2. Green Accounting Index

\begin{tabular}{cc}
\hline Index Value & Category \\
\hline $2.8-6.5$ & Low \\
$6.6-10.2$ & Moderate \\
$10.3-14$ & High \\
\hline
\end{tabular}




\section{Financial Literacy}

Financial literacy rates are measured by questionnaire with 3 dimensions and 21 indicators that are referred to the survey instrument to measure the financial literacy of MSMEs by OECD [31]. The dimensions are financial knowledge with 8 indicators, financial behavior with 7 indicators, and financial attitudes with 6 indicators (see Appendix B). The correct responses will be given score " 1 ", and the score " 0 " will be given for other responses. Financial literacy scores are created simply by summing the number of correct responses from entire financial literacy questions. While the financial literacy rates are obtained from the percentage of correct answers from the total of questions. Then, its percentage is divided into three categories based on Developing Indonesian Financial Literacy Index (2013) [32] that showed in Table 3.

Table 3. Financial Literacy Index (FLI)

\begin{tabular}{cc}
\hline Index (\%) & Category \\
\hline $0 \leq \mathrm{FLI} \leq 60 \%$ & Low \\
$60 \%<\mathrm{FLI} \leq 80 \%$ & Moderate \\
FLI $>80 \%$ & High \\
\hline
\end{tabular}

\section{Financial Performance}

In this study, financial performance is measured by profitability ratio analysis, which consists of net profit margin (NPM), return on asset (ROA), and return on equity (ROE) [33]. Refers to a previous study that measures financial performance using revenue, profitability, and ROE, said that even though those are not cover all the forms of financial measures but those are emphasizes SME's area concern, reflect growth indicator, and competitive strategy [34]. Then, the profitability ratio is classified based on profitability ratio standard by the Ministry of Cooperatives and SMEs of Republic Indonesia No. 06 (2006) [35] as presented in Table 4.

Table 4. Profitability ratio standard

\begin{tabular}{cll}
\hline Ratio & \multicolumn{1}{c}{ Standard } & \multicolumn{1}{c}{ Category } \\
\hline & $\mathrm{NPM}<1 \%$ & Very unhealthy \\
Net Profit Margin (NPM) & $1 \% \leq \mathrm{NPM}<5 \%$ & Not healthy \\
$=\frac{\text { Net Income }}{\text { Sales }}$ & $5 \% \leq \mathrm{NPM}<10 \%$ & Unsufficient healthy \\
& $10 \% \leq \mathrm{NPM}<15 \%$ & Sufficient healthy \\
& $\mathrm{NPM} \geq 15 \%$ & Healthy \\
\hline Return on Asset (ROA) & ROA $<1 \%$ & Very unhealthy \\
\hline
\end{tabular}




\begin{tabular}{cll}
\hline \multicolumn{1}{c}{ Ratio } & \multicolumn{1}{c}{ Standard } & \multicolumn{1}{c}{ Category } \\
\hline Net Income & $1 \% \leq \mathrm{ROA}<3 \%$ & Not healthy \\
Total Asset & $3 \% \leq \mathrm{ROA}<7 \%$ & Unsufficient healthy \\
& $7 \% \leq \mathrm{ROA}<10 \%$ & Sufficient healthy \\
& $\mathrm{ROA} \geq 10 \%$ & Healthy \\
\hline \multirow{2}{*}{ Return on Equity (ROE) } & $\mathrm{ROE}<3 \%$ & Very unhealthy \\
$=\frac{\text { Net Income }}{\text { Equity }}$ & $3 \% \leq \mathrm{ROE}<9 \%$ & Not healthy \\
& $9 \% \leq \mathrm{ROE}<15 \%$ & Unsufficient healthy \\
& $15 \% \leq \mathrm{ROE}<21 \%$ & Sufficient healthy \\
& $\mathrm{ROE} \geq 21 \%$ & Healthy \\
\hline
\end{tabular}

\section{3 Data Analysis}

Quantitative analysis are used in this study to analyze the relationship between each variable. The quantitative analysis used in this study are statistics descriptive analysis to measure the implementation of green accounting and financial literacy rate, profitability ratio to measure financial performance, and kendall-tau correlation test with IBM SPSS 22 software to measure the correlation coefficient between the variables.

The kendall-tau correlation test is used to see the relationship between each variable in this study. This correlation test is fit in this study because the data is ordinal and the data does not have to meet the assumption of normality test. The coefficient correlation is in the interval -1 to 1 . If the correlation number gets closer to 1 , then the relationship between the two variables is declared perfect. In addition, if there are two stars $\left(^{* *}\right)$ in the correlation table, then the relationship has a very real meaning, whereas if there is only one star $\left(^{*}\right)$ it means that it has real meaning, and if there are no stars it means that it does not indicate a significant relationship. The interpretation of the correlation coefficient can be seen in Table 5 .

Table 5. Interpretation of coefficient correlation

\begin{tabular}{cc}
\hline Coefficient Correlation & Interpretation \\
\hline $0-0.199$ & Very weak \\
$0.20-0.399$ & Weak \\
$0.40-0.599$ & Moderate \\
$0.60-0.799$ & Strong \\
$0.80-1.0$ & Very Strong \\
\hline
\end{tabular}




\section{Result and Discussion}

The Sukaregang tannery industrial center is one of the main industries in supporting the footwear and other leather goods industries such as coats, jackets, belts, gloves, and wallets. The impact of the leather tanning industry can be seen from the economic and environmental perspectives. From the economic perspective, the leather industry center industry can contribute significantly to the economy, tourism, and absorption of local labor. Meanwhile, if it's seen from an environmental perspective, the center of the Sukaregang tannery industry is the main source of water pollution.

The management of solid waste from the leather tanning process which is classified as hazardous and toxic waste materials is still being dumped illegally and there is still a lot of leather industry waste that is disposed of directly into the environment without going through any treatment process first. This is indicated by the absence of reporting on the amount of waste generated from the tanners in Sukaregang to the Environmental Services of Garut. Besides that, all of the tannery industries have yet to have a permit to dispose of liquid waste into the environment and a permit to dispose of solid waste at the Waste Disposal Site.

Until now, the tannery industry waste in Sukaregang is still an ongoing problem. The rivers in the Sukaregang area affected by tannery waste include the Ciwalen River (west of Sukaregang) and Cigulampeng (east of Sukaregang). The two rivers are part of the Cimanuk River tributary.

This environmental pollution is felt by the people who live around the river, which is flowed by the Sukaregang tannery industrial waste. The pungent odor caused by liquid waste which is dark black has greatly disturbed the activities of the surrounding community. Some residents also said that the liquid waste had absorbed into residents 'wells and also flowed into residents' agricultural lands. Therefore, in 2018 the people affected by the liquid waste vented their anger by shedding the liquid waste onto the road. Then in 2019, the community affected by the liquid waste returned to do the same thing and they hope that the tannery industrial center was moved to a place far from residential areas because the waste was considered very disturbing.

In this study, green accounting is a variable used as a form of a quantitative assessment of the cost and effectiveness of a company in protecting its environment [36]. Table 6 shows the level of implementation of green accounting in the Sukaregang tannery industry. 
Table 6. Percentage of green accounting implementation level

\begin{tabular}{ccc}
\hline Category & Frequency & Percentage (\%) \\
\hline Low & 5 & 35.72 \\
Moderate & 8 & 57.14 \\
High & 1 & 7.14 \\
\hline
\end{tabular}

It can be seen in Table 6, the level of implementation of green accounting for tanners in Sukaregang is mostly included in the moderate category with a percentage of $57.14 \%$, followed by tanners who have a low level of green accounting implementation with a percentage of $35.14 \%$ and only one industry or $7.14 \%$ included in the high category in the implementation level of green accounting. This shows that the majority of the tannery industry is still ineffective in terms of protecting the environment. It can also be seen from the waste disposal system that has not been managed properly, so that industrial waste causes pollution to the surrounding environment.

Apart from dealing with waste problems, Sukaregang tanners are also currently facing problems regarding the impact of competitiveness due to the Asean Economic Community (AEC) policy since 2015. In 2016, the number of tannery industries in Sukaregang was 387 tanners. However, the impact of the AEC free-market competition has made the number of tanners decrease every year. It can be seen that in 2019 only 282 tanners who can survive to sustain their business. Apart from the impact of competition, the cause of the decline in the number of tanners in Sukaregang is also because many tanners have switched their professions to become entrepreneurs of leather handicraft products because they tend to have less risk.

According to a questionnaire survey conducted, as many as $64.3 \%$ of the tanners who were respondents in this study started their business because of a hereditary business. Therefore, the knowledge and skills the tanners in Sukaregang in running their business are still being learned from their parents and are still being self-taught. Hence, the financial management of the business is still not well managed. The ability to manage a business's finances can be affected by the level of financial literacy [37]. Table 7 shows the level of financial literacy in the Sukaregang leather tanning industry.

Table 7. Financial literacy level

\begin{tabular}{ccc}
\hline Category & Frequency & Percentage (\%) \\
\hline Low & 7 & 42.86 \\
Moderate & 4 & 28.57 \\
High & 3 & 28.57 \\
\hline
\end{tabular}


Based on Table 7, it can be seen that the majority of owners of the tannery industry in Sukaregang have a low level of financial literacy with a percentage of $42.86 \%$. Then followed by tanners who had a moderate and low level of financial literacy, with the same percentage of $28.57 \%$. The level of financial literacy of MSME owners has a positive impact on the financial performance of an MSME. Therefore, a high level of literacy can improve the financial performance of the Sukaregang tanning industry, which is still classified as MSMEs [38, 39]. Based on the results of research that has been done, the financial performance of the Sukaregang tannery industry can be seen in Table 8.

Table 8. Mean of profitability ratio

\begin{tabular}{ccc}
\hline Indicators & Mean of Ratio & Category \\
\hline NPM & 0.156 & Healthy \\
\hline ROA & 0.092 & Sufficient Healthy \\
\hline ROE & 0.205 & Sufficient Healthy \\
\hline
\end{tabular}

Based on Table 8, the mean profitability ratio measured using NPM is 0.156 and included in the healthy category which shows that the industry average earns a net profit of $\mathrm{Rp} 0.156$ for every $\mathrm{Rp} 1$ sale. The mean profitability ratio measured using ROA is 0.092 and included in the sufficient healthy category which indicates that for every Rp1 asset that is used, the industry average is able to get a net profit of $\mathrm{Rp} 0.092$. Furthermore, the mean profitability ratio measured using ROE is 0.205 and included in the sufficient healthy category which shows that for every Rp1 capital used, the industry average is able to get a net profit of Rp0.205.

Then the variables in this study were analyzed quantitatively to determine the relationship between each variable using a statistical test, namely the kendall-tau correlation test with ordinal scale data types. The following is the result of the kendall-tau correlation test, which can be seen in Table 9. 
Table 9. Correlation coefficients of rank spearman test

\begin{tabular}{ccccccc}
\hline Variables & $\begin{array}{c}\text { Green } \\
\text { Accounting }\end{array}$ & $\begin{array}{c}\text { Financial } \\
\text { Literacy }\end{array}$ & $\begin{array}{c}\text { Industry } \\
\text { Category }\end{array}$ & ROA & ROE & NPM \\
\hline Green Accounting & 1 & & & & & \\
\hline Financial Literacy & $0.601^{*}$ & 1 & & & & \\
\hline Industry Category & $0.642^{*}$ & 0.395 & 1 & & & \\
\hline ROA & -0.113 & 0.263 & 0.129 & 1 & & \\
\hline ROE & -0.211 & -0.224 & -0.246 & 0.255 & 1 & \\
\hline NPM & -0.497 & -0.307 & -0.355 & 0.393 & $0.595^{*}$ & 1 \\
\hline
\end{tabular}

Based on Table 9, it can be seen that financial literacy and green accounting have a strong level of relationship with a correlation coefficient of 0.601 . This shows that tanners who have implemented green accounting well tend to have high levels of financial literacy. Therefore, good financial literacy is needed as an effort to implement green accounting. The industry category has a strong relationship with green accounting with correlation coefficients of 0.642 . This shows that the larger the industry's category, the better the implementation level of green accounting. Meanwhile, the financial performance variables measured using ROA, ROE, and NPM did not show a significant relationship, both with green accounting and financial literacy variables.

Based on the research results, the average financial performance of the leather tanning industry in Sukaregang is quite healthy, although the implementation of green accounting has not been implemented properly, so it does not show a direct relationship between green accounting and financial performance. However, the implementation of green accounting in the tannery industry is thought to have an indirect relationship to financial performance. This is because implementing green accounting will have a positive impact on environmental performance, thereby increasing the competitiveness ability of tanners in the AEC market. In line with the increasing ability to compete in the AEC market, the sales of tanned leather products also tend to increase. Consumer's willingness-to-pay will increase with their reliance on the offered value of green products; thus necessitating the enhanced need for green product innovation with improved performance, quality consideration, and economical pricing strategy [40]. Therefore, this will have a positive impact on the financial performance of the leather tanning industry. Research conducted by Chen et al. (2018) supports this statement. That research shows that green initiatives have a positive influence on environmental performance, while it has a negative impact on financial performance. However, on the other hand, the environmental performance has a positive influence on financial performance. 
Therefore, it can be seen that green initiatives have an indirect effect on financial performance [41].

In an effort to increase competitiveness in this AEC era, MSMEs also need to pay attention to the quality of the products. However, knowledge about the tannery production process in Sukaregang is still acquired from their parent and studied independently. So that the quality of the products produced is still unable to compete with products produced by large-scale tannery industries. Therefore, training regarding the leather tanning process is also needed in order to produce quality products that can be competitive with products produced by large industries.

The decline in the number of the leather tanning industry was also influenced by the poor management pattern of the owners of the leather tanning industry in Sukaregang. The ability of the owners of the Sukaregang tannery industry in managing finances is still low. This can be seen from the results of survey which showed that the average level of financial literacy of tanners in Sukaregang is still low. Tanneries with low levels of financial literacy tend to have poor financial management attitudes. With poor financial management, the tannery industry tends to have an unhealthy financial performance. Therefore, many tannery industries are unable to maintain their business.

\section{Conclusion and Recommendation}

Based on the results that has been carried out and described in the previous discussion, it is found that the level of implementation of green accounting for tanners in Sukaregang is mostly included in the moderate category with a percentage of $57.14 \%$, and the majority of owners of tannery industry in Sukaregang have a low level of financial literacy with a percentage of $42.86 \%$. Green accounting and financial literacy has a strong correlation with a correlation coefficient of 0.601 . However, green accounting and financial literacy do not have a significant correlation with financial performance.

From this research, there are some suggestions for several parties. (1) For the tannery industry in Sukaregang, there is a need for efforts to manage industrial waste so as not to pollute the surrounding environment. One of the efforts that can be done is by implementing green accounting. However, before implementing green accounting, tanneries should improve financial literacy in order to optimally implement green accounting. This may need to start with improving the owner's environmental knowledge and awareness. Sustainability of life on this planet rests in the hands of sustainable industries [23]. (2) For the local government, it is necessary to participate in efforts to manage the industrial 
waste of the tannery industry in Sukaregang. One of the efforts that can be done is to improve the waste management installation facilities that have been made so that they can be used by tanners in Sukaregang. (3) For future research, it is better to use a larger number of samples so that the results are more representative.

\section{References}

[1] Statistics Indonesia. Perkembangan Indeks Produksi Industri Manufaktur Besar dan Sedang 2017-2019. Jakarta (ID): Central Bureau of Statistics; 2019.

[2] Statistics Indonesia. Pertumbuhan Ekonomi Indonesia Triwulan IV-2019. Jakarta (ID): Central Bureau of Statistics; 2020.

[3] Statistics Indonesia. Indeks Produksi Industri Besar dan Sedang Menurut Dua Digit Kode ISIC, 2010-2019 (2010=100). Jakarta (ID): Central Bureau of Statistics; 2020.

[4] Statistics Indonesia. Indeks Produksi Triwulanan Industri Mikro dan Kecil $(2010=100)$ Menurut Provinsi, 2011-2019. Jakarta (ID): Central Bureau of Statistics; 2020.

[5] Ridwan, IR. Dampak Industri terhadap Lingkungan dan Sosial. Jurnal Geografi. 2007, $7(2)$.

[6] Statistics Indonesia. Statistik Lingkungan Hidup Indonesia 2018. Jakarta (ID): Central Bureau of Statistics; 2018.

[7] Elkington, J. Cannibals with Forks: The Triple Bottom Line of Twentieth Century Business. Oxford (UK): Capstone Publishing; 1997.

[8] Chowdhury et al. Characterization of the Effluents from Leather Processing Industries. Environmental Process. 2015, 2: 173-187.

[9] Dargo H, Ayalew A. Tannery Waste Water Treatment: A Review. International Journal of Emerging Trends in Science and Technology. 2014, 1(9): 1488-1494.

[10] Senthil R, Hemalatha T, Manikandan R, Das BN, dan Sastry TP. Leather Board from Buffing Dust: A Novel Perspective. Clean Technologies and Environmental Policy. 2015, 17(2): 571-576.

[11] Ministry of Trade of the Republic of Indonesia. Indonesia's Leather Industry: One of the National Outstanding Sector. Jakarta (ID): Kementrian Perdagangan RI; 2018.

[12] Ministry of Environment and Forestry of the Republic of Indonesia. Atlas Status Mutu Air Indonesia Tahun 2016. Jakarta (ID): Ministry of Environment and Forestry; 2016.

[13] Patnaik, R. Impact of Industrialization on Environment and Sustainable Solutions Reflections from a South Indian Region. IOP Conf. Series: Earth and Environmental Science. $120012016,2018$.

[14] Rounaghi, MM. Economic analysis of using green accounting and environmental accounting to identify environmental costs and sustainability indicators. International Journal of Ethics and Systems. 2019, Vol. 35 (4): 504-512.

[15] Kumar NA, Pranitha TS, Kumar NK. A Study on Green Accounting and Its Practices in India. IOSR Journal of Business and Management. International Conference on "Paradigm Shift in Taxation, Accounting, Finance, and Insurance. 2017, Vol. 1: 30-34

[16] Nielsen. A 'Natural' Rise In Sustainability Around The World Cpg, Fmcg \& Retail. 2019, [internet]. [accessed on June 24th, 2020]. Available at 
https://www.nielsen.com/eu/en/insights/article/2019/a-natural-rise-in-sustainabilityaround-the-world/

[17] Nielsen. Global Consumers Are Willing To Put Their Money Where Their Heart Is When It Comes To Goods And Services From Companies Committed To Social Responsibility. 2014, [internet]. [accessed on June 24th, 2020]. Available at: https://www.nielsen.com/us/en/press-releases/2014/global-consumers-are-willing-to-puttheir-money-where-their-heart-is/

[18] Young, K. The Rise of Green Consumerism: What do Brands Need to Know?. 2018, [internet]. [accessed on May 14th, 2020]. Available at: https://blog.globalwebindex.com/chart-of-the-week/green-consumerism/)

[19] White K, Hardisty DJ, Habib R. The Elusive Green Consumer. 2019, [internet]. [accessed on May 14th, 2020]. Available at: https://hbr.org/2019/07/the-elusive-green-consumer

[20] Karvonen, MM. Environmental accounting as a tool for SMEs in environmentally induced economic risk analysis. Corporate Social Responsibility and Environmental Management. 2000, 7(1): 21-28.

[21] Garut Leather Industry Development Service Unit. Data Jumlah Industri Penyamakan Kulit Sukaregang Gatut 2016-2019.

[22] Ministry of Industry. Daya Saing RI Lemah Hadapi MEA [internet]. [accessed on March 27th, 2020]. Available at: https://www.kemenperin.go.id.

[23] Nulkar, G. International Conference on Trade, Markets and Sustainability SMEs and Environmental Performance - A framework for Green Business Strategies. Procedia Social and Behavioral Sciences 00 (2012) 000-000.

[24] Ye J, Kulathunga KMMCB. How Does Financial Literacy Promote Sustainability in SMEs? A Developing Country Perspective. Sustainability. 2019, 11, 2990.

[25] Lusardi A, Mitchell OS. The economic importance of financial literacy: Theory and evidence. 2014, 52: 5-44.

[26] Financial Services Authority. Press Release OJK and Ministry Team Up to Develop MSMEs. Jakarta, July 2016. SP - 66/DKNS/OJK/7/2016

[27] Theoh HY, Thong G. Another Look at Corporate Social Responsibility and Reporting: An Empirical Study in A Developing Country. Accounting, Organizations, and Society. 1984, 9(2): 189-206.

[28] Jahamani, YF. Green Accounting in Developing Countries: The Case of U.A.E., and Jordan. Managerial Finance. 2003, 29(8): 37-45.

[29] Dunk, AS. Product Quality, Environmental Accounting and Quality Performance. Accounting, Auditing, and Accountability Journal. 2002, 15(5): 719-732.

[30] Ferdinand, AT. Metode Penelitian Manajemen. Semarang (ID): Badan Penerbit Universitas Diponegoro; 2006.

[31] [OECD] Organisation for Economic Co-operation and Development. OECD/INFE Toolkit for Measuring Financial Literacy and Financial Inclusion. 2016, [Internet]. [accessed on January 19th, 2020]. Available at: https://www.oecd.org

[32] Definit. Final Report: Developing Indonesian Financial Literacy Index. 2013, [Internet]. [accessed on March 15th, 2020]. Available at: http://definit.asia/

[33] Tampubolon, MP. Manajemen Keuangan. Edisi Pertama. Jakarta (ID): Ghalia Indonesia; 2005.

[34] Jayeola, O. The Impact of Environmental Sustainability Practice on the Finance Performance of SMEs: A Study of Some Selected SMEs in Sussex. International Journal of Business Management and Economics. 2018, 6(4): 214-230. 
[35] Minister of Cooperatives and MSMEs. Regulation of the State Minister for Cooperatives and MSMEs of the Republic of Indonesia Number 06/Per/M.KUKM/V/2006. The Standard for Measuring The Profitability Ratio of An MSMEs.

[36] Ministry of the Environment Japan. Environmental Accounting Guidelines. Tokyo (JP): Ministry of the Environment; 2005.

[37] Anggraeni, BD. Pengaruh Tingkat Literasi Keuangan Pemilik Usaha terhadap Pengelolaan Keuangan (Studi Kasus: UMKM Depok). Jurnal Vokasi Indonesia. 2015, 3(1): 22-30.

[38] Agyapong D, Attram AB. Effect of Owner-Manager's Financial Literacy on the Performance of SMEs in the Cape Coast Metropolis in Ghana. Journal of Global Entrepreneurship Research. 2019, 9(67): 1-13.

[39] Tuffour JK, Amoako AA, Amartey EO. Assessing the Effect of Financial Literacy Among Managers on the Performance of Small-Scale Enterprises. Global Business Review. 2020, pp. 1-18.

[40] Biswas, A. A Study of Consumers' Willingness to Pay for Green Products. Journal of Advanced Management Science. 2016, Vol. 4 (3).

[41] Chen F, Ngniatedema T, Li S. A Cross-Country Comparison of Green Initiatives, Green Performance, and Financial Performance. Management Decision. 2018, 56(5): 1008-1032. 


\section{Appendix}

\section{Appendix A}

Table A1. Measurement of green accounting variable

\begin{tabular}{|c|c|c|}
\hline Dimensions & Indicator & Source \\
\hline \multirow{6}{*}{$\begin{array}{l}\text { Environmental } \\
\text { Awareness }\end{array}$} & Legislation e.g. environmental quality act & \multirow{6}{*}{$\begin{array}{c}\text { Teoh and } \\
\text { Thong (1984) }\end{array}$} \\
\hline & Philosophy of top management & \\
\hline & Suggestions from individual employee & \\
\hline & Suggestions from customers & \\
\hline & Suggestions from enviromental agency e.g. WALHI & \\
\hline & Suggestions from society communities & \\
\hline \multirow{4}{*}{$\begin{array}{l}\text { Environmental } \\
\text { Protection }\end{array}$} & Company's human and economic resources & \multirow{4}{*}{$\begin{array}{l}\text { Jahamami } \\
(2003)\end{array}$} \\
\hline & Safely dispose of industrial waste & \\
\hline & Safely dispose of industrial waste in spite of its losses & \\
\hline & $\begin{array}{l}\text { Safely dispose of industrial waste even if it has to shut } \\
\text { down }\end{array}$ & \\
\hline \multirow{4}{*}{$\begin{array}{l}\text { Environmental } \\
\text { Involvement }\end{array}$} & Environmental unit & \multirow{4}{*}{$\begin{array}{l}\text { Jahamami } \\
(2003)\end{array}$} \\
\hline & Budgeting for environmental protection & \\
\hline & $\begin{array}{l}\text { Program and procedures to reduce natural resources } \\
\text { consumption }\end{array}$ & \\
\hline & Environmental attributes of machinery safety guide & \\
\hline \multirow{10}{*}{$\begin{array}{l}\text { Environmental } \\
\text { Reporting }\end{array}$} & Reduction or elimination of process waste & \multirow[t]{10}{*}{ Dunk (2002) } \\
\hline & Tracing costs to environmental activities & \\
\hline & $\begin{array}{l}\text { Envitonmental considerations in investment } \\
\text { decisions/trade-offs }\end{array}$ & \\
\hline & $\begin{array}{l}\text { Design decisions influenced by environmental } \\
\text { considerations }\end{array}$ & \\
\hline & Customers and other stakeholders & \\
\hline & To improve compliance with environmental standards & \\
\hline & To support sustained profit growth & \\
\hline & $\begin{array}{l}\text { To identification of product material with environmenta } \\
\text { downsides }\end{array}$ & \\
\hline & $\begin{array}{l}\text { To reduction or elimination of product material with } \\
\text { environmental downsides }\end{array}$ & \\
\hline & Record environmental activity costs & \\
\hline
\end{tabular}




\section{Appendix B}

Table B2. Measurement of financial literacy variable

\begin{tabular}{|c|c|c|}
\hline Dimensions & Indicator & Source \\
\hline Financial & Simple interest & OECD (2019) \\
\hline \multirow[t]{8}{*}{ Knowledge } & Compound interest & \\
\hline & Balance sheet & \\
\hline & Return on Asset (ROA) & \\
\hline & Dividends & \\
\hline & Investor & \\
\hline & Investment & \\
\hline & Inflation & \\
\hline & Profit and loss & \\
\hline \multirow{7}{*}{$\begin{array}{l}\text { Financial } \\
\text { Behaviour }\end{array}$} & Keeping track of financial records & OECD (2019) \\
\hline & Strategies to cope with theft & \\
\hline & Security of data and information about the business & \\
\hline & Decision to invest & \\
\hline & Monitoring business financial positions & \\
\hline & Forecast the profitability of the business regularly & \\
\hline & Follow changes in economic factors & \\
\hline \multirow{5}{*}{$\begin{array}{l}\text { Financial } \\
\text { Attitudes }\end{array}$} & Set long term financial goals & OECD (2019) \\
\hline & Taking a risk & \\
\hline & Financing the business & \\
\hline & Financial planning & \\
\hline & $\begin{array}{l}\text { Consideration of environmental, social, and governance } \\
\text { factors }\end{array}$ & \\
\hline
\end{tabular}

